\title{
POPULATION STATUS AND MANAGEMENT OF TRUMPETER SWANS IN SASKATCHEWAN
}

\author{
by D. J. NIEMAN and R. J. ISBISTER*
}

Once ranging as a breeding bird over a large portion of the central Great Plains, the Trumpeter Swan has been virtually eliminated from most of its former range by destruction of habitat. ${ }^{2} 2{ }^{14}$ From a population of several dozen in 1916 this magnificant bird has made a remarkable comeback in North America and probably exceeds 4,000 individuals at present. ${ }^{9}$.

In the United States, Trumpeter Swans are restricted to several northwestern states and southern Alaska. In Canada this species winters in British Columbia and breeds in small numpers in Alberta and Saskatchcwan. ${ }^{2} \& 12$ The status of the Trumpeter Swan in Saskatchewan from the irst recorded sightings in the province 1914) until 1971 was reviewed in an arlier paper. ${ }^{12}$ Since then, additional nvestigations have changed our knowledge of the status of this species $\mathrm{n}$ the province.

In 1972, the Canadian Wildlife Serice implemented a program of esearch and management on Saskathewan Trumpeters. Management is imed at providing complete protecion and collecting annual population ata. ${ }^{10}$ "Investigations into breeding iology, habitat relationships, morality, migration routes and wintering rounds of Saskatchewan Trumpeters re underway. The objective is to assist their preservation and to expand

Canadian Wildlife Service,

rairie Migratory Bird Research Centre, askatoon, Sask. their present breeding range in Saskatchewan.

\section{Methods and Objectives}

To provide protection, special posters were erected around all known breeding areas, warning against the killing or molestation of these birds. These signs are maintained through twice annual checks by Canadian Wildlife Service personnel. Information provided to landowners, federal and provincial enforcement personnel and other government officials served to provide additional protection.

Annual aerial surveys have been conducted in the Cypress Hills and other areas of Saskatchewan where Trumpeter Swans have been reported during the breeding season. These surveys have provided data on the location and size of the breeding population, the number of cygnets fledged, brood movement and fall distribution.

Breeding pair surveys were carried out May 31 and May 25 and the brood surveys July 24 and August 10 in 1972 and 1973, respectively. One fall aerial survey was conducted on September 5, 1972, and a search for new breeding areas on August 10, 1973. Investigations into the breeding biology and an evaluation of habitat requirements were conducted on the ground on June 6, 1972, and May 28, 1973. Information was collected on nest location, size and construction, 


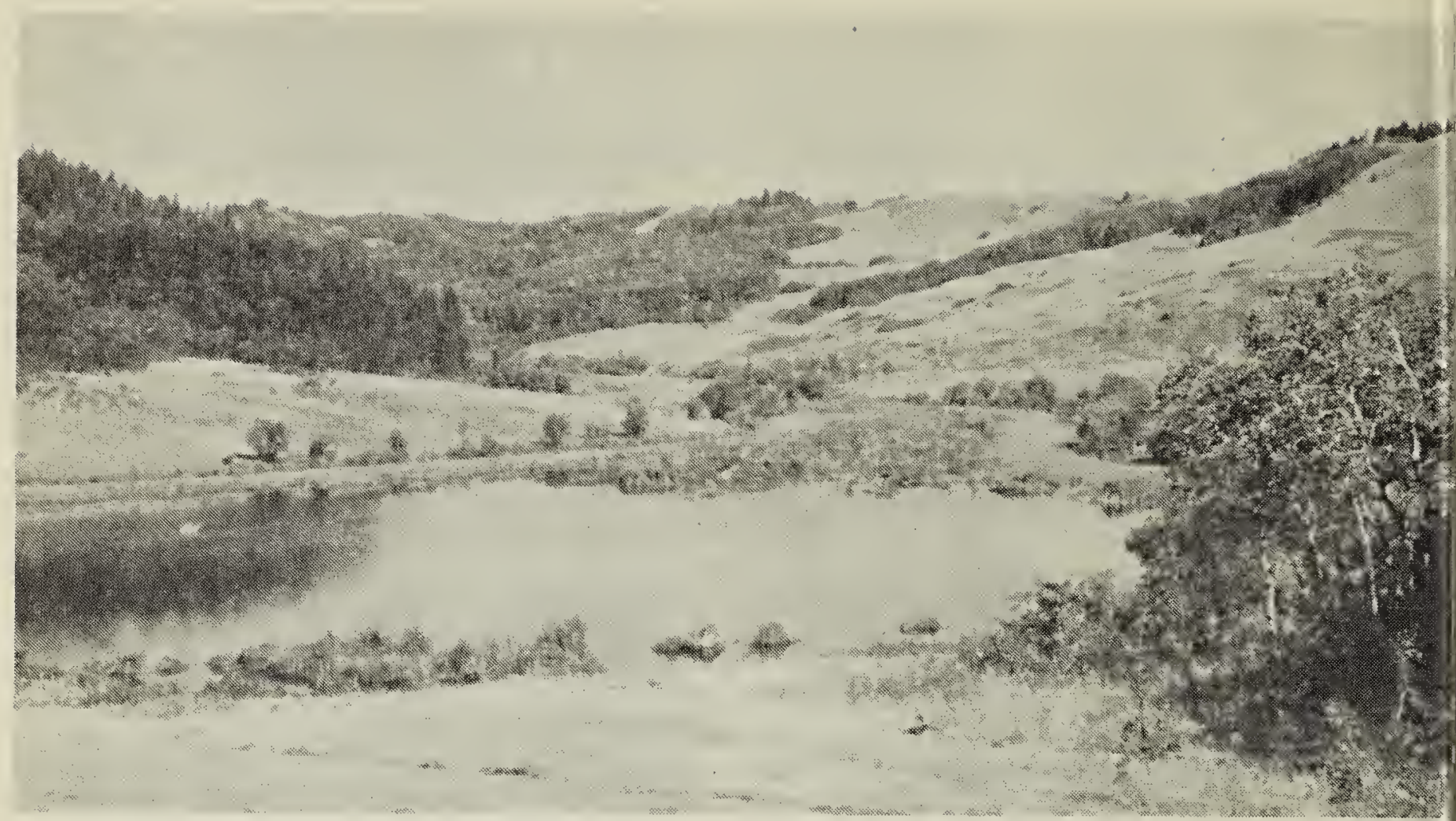

Trumpeter Swan nesting habitat in the Cypress Hills, Saskatchewan.

D. J. Nieman

clutch sizes and the physical characteristics of the water areas used for breeding.

Cygnets and adults (flightless during the moult) have been banded and colour-marked for the past 2 years to obtain information on mortality, migration routes and wintering grounds, so far undetermined. This information may explain, partially, why this population has not expanded in recent years. Yellow plastic neck collars and matching leg bands with identifying numbers and letters were applied in addition to the standard metal leg bands.

\section{Results}

Three Trumpeter Swan nests were located in the Cypress Hills on May 31, 1972. They were on the same areas as in 1971 - two lakes and a beaver pond. No non-breeding swans were observed during this survey.

Clutch of 6 and 7 eggs and 5 recently hatched cygnets were observed during ground investigations on June 6 and 7. On a July 24 aerial survey, broods of two, two and four were seer with the adults. We banded one adul female and four cygnets. None wa: colour-marked.

All 10 young and 6 adults were aliv and flying on September 5. The 1971 population of 16 Trumpeter Swans it the Cypress Hills region was the sam as the previous year and equal to th highest population recorded in Saskat chewan.

The Cypress Hills population drop ped to two pairs in 1973. An aeria survey on May 25 was again unsuc cessful in locating sub-adult swans The reasons for this are not clear, a Trumpeter cygnets reportedly returi to their natal marshes each breedin season until they attain maturity believed to be four years. ' Ground in vestigations conducted on May 2 revealed two nests with 6 and 5 eggs or a lake and beaver pond used in th previous two years.

Two pairs of Trumpeters, each witl a brood of three cygnets, were locater during an aerial survey on August 10 On August 21, one adult female fron 


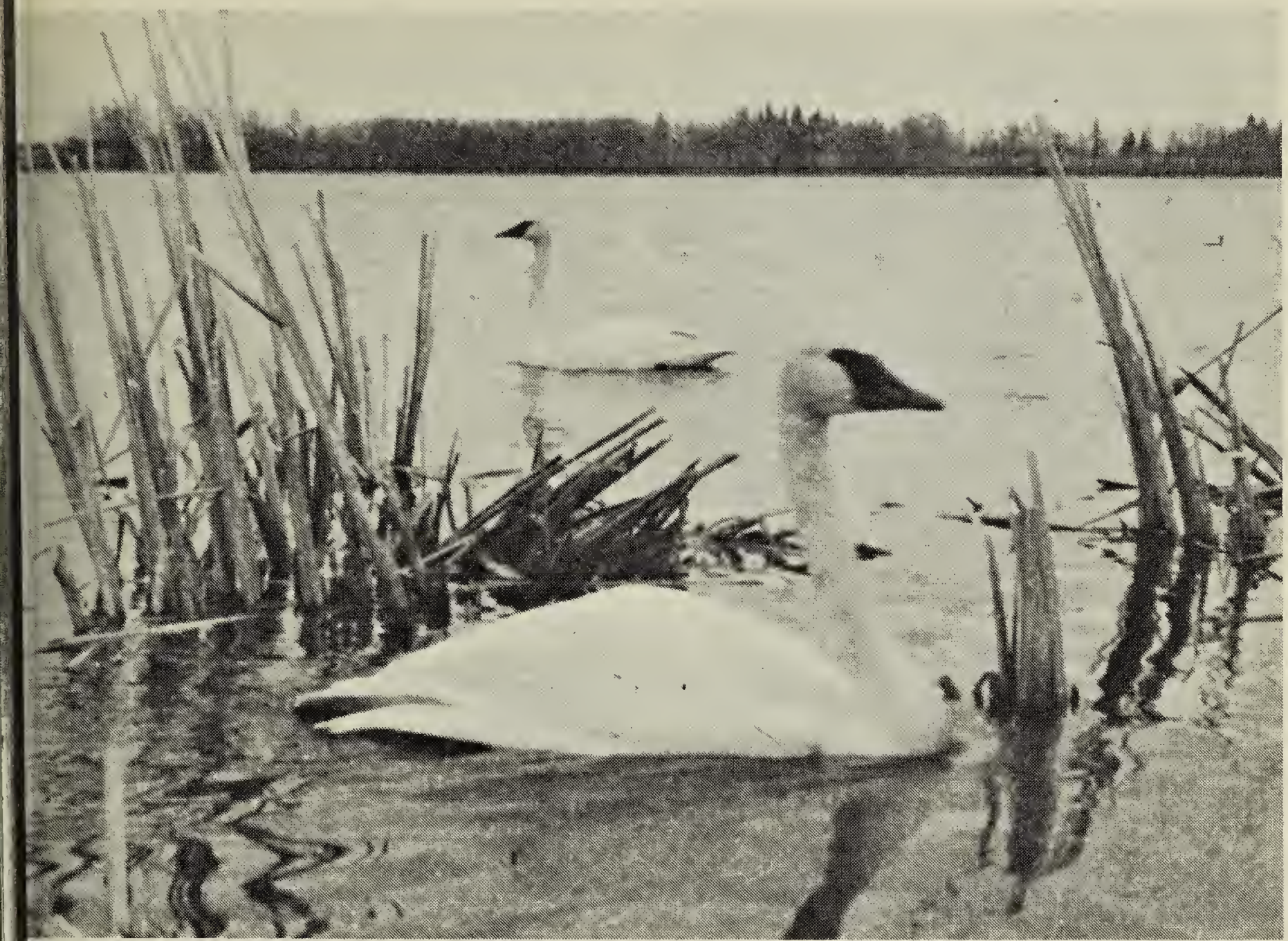

dult Trumpeter Swans near the nest.

R. H. MacKay

ach family group and all six cygnets ere banded. These eight birds were so colour-marked with plastic neck pllars and tarsal bands. It would apar that there were 10 Trumpeter wans in the Cypress Hills in the fall of 973, six fewer than the previous 2 ears.

On August 17, 1973, we found lother population of Trumpeter wans on three isolated lakes in the pen parklands between Meadow ake and North Battleford. There ere one pair of adults with a brood of ro cygnets and two non-breeders, lieved to be sub-adults.

\section{scussion}

First reported in Saskatchewan in 14 and first recorded as breeding in e Cypress Hills in 1951,137 this pulation of Trumpeter Swans flucated between one and two pairs (plus an occasional non-breeder) until 1971.3 ${ }^{6}$ The breeding population remained at three pairs during 1971 and 1972 when 9 and 10 cygnets, respectively, were fledged. In 1973, the breeding population dropped to two pairs. Six cygnets probably migrated south with them.

The banding and colour-marking program will hopefully reveal which factors are limiting the size of this isolated breeding population. The loss of even one nesting territory or breeding pair will seriously jeopardize the survival of this group unless there is sufficient recruitment. However, the population is not expanding and, although this species requires large breeding territories, there seems sufficient habitat in the Cypress Hills to support additional pairs. ${ }^{4}$

Cygnet mortality may be high during migration and on wintering grounds, 


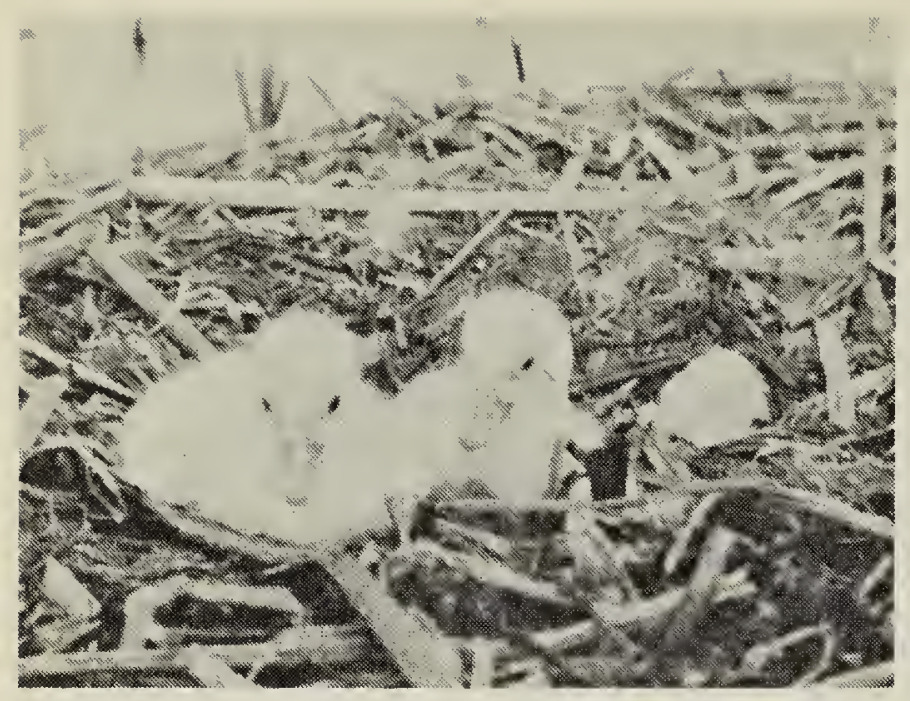

R. H. MacKay. Newly hatched Trumpeter Swan cygnets on the nest.

or young from the Cypress Hills may be contributing to some other population. Banding and colourmarking may provide important answers.

This research indicates that differences do exist between this and other breeding populations. Saskatchewan swans have a shorter breeding season than some of the more southerly populations and clutch sizes average slightly larger. The shorter breeding season is probably a factor of the latitude of the breeding areas, and the larger clutch sizes could be an indication of unsaturated breeding habitat. Our observations have shown that Saskatchewan Trumpeters will tolerate Canada Geese and nonbreeding Trumpeters on their territories and they appear to lack the brood attentiveness exhibited elsewhere.

Prior to 1973, only two relatively stable breeding populations of this species were known in Canada - at Grande Prairie, Alberta, and in the Cypress Hills of Saskatchewan. ${ }^{12}$ The discovery of breeding swans in westcentral Saskatchewan indicates that additional suitable habitat exists and that perhaps recruitment from the Cypress Hills flock to other areas of the province is occurring. Con- tinuation of the colour-markin scheme could substantiate this.

The Canadian Wildlife Service presently considering the possibility o a transplant program involving th relocation of Trumpeter Swans fron established breeding populations int suitable habitat in Saskatchewan However, a successful introductio program should not be implemente until basic population data, includin a determination of the winterin grounds, migration routes and factor limiting the population size of th existing swans in Saskatchewan ar known. A successful introductio program also would depend upon th protection given these birds o breeding and wintering grounds.

\section{Acknowledgements}

The authors wish to express thei gratitude to the Jim Leslie and C Harley Bryan families of the Cypres Hills for their genuine hospitality an full cooperation in our field activitie Their special interest in the Cypres Hills Trumpeter Swans, which has en sured the protection of these birds o their breeding areas, is deeply ap preciated.

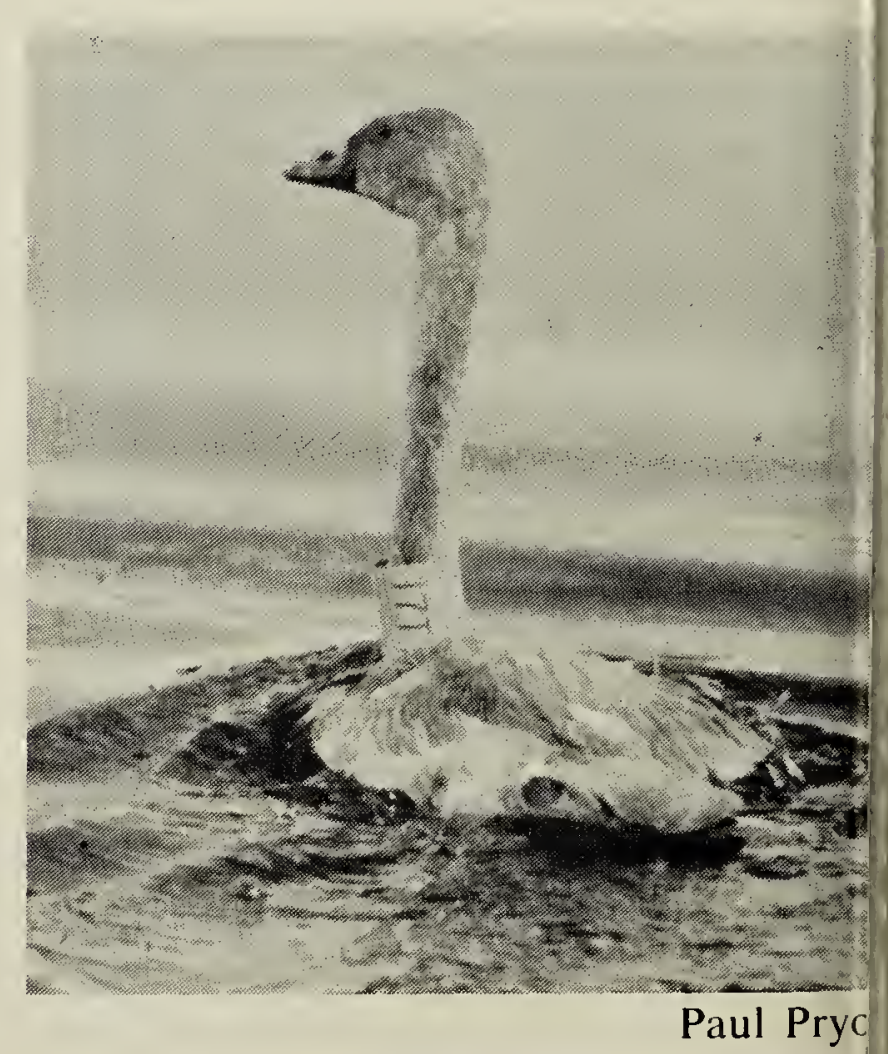

Trumpeter Swan cygnet with plastic colle 
Special thanks go to John Worthington, Royal Canadian Mounted Police, for assistance during several aerial surveys. We gratefully acknowledge the contributions of Cliff Matthews, Canadian Wildlife Service, Ross Hanson, U.S. Bureau of Sport Fisheries and Wildlife, and Wayne Renaud who were instrumental in our discovery of the Trumpeter breeding area in west-central Saskatchewan.

${ }^{\prime} \mathrm{BANKO}$, W. E. 1960. The Trumpeter Swan. North American fauna, 63, U.S. Dept. Interior, Washington. $214 \mathrm{pp}$.

BANKO, W. E. and R. H. MacKAY. 1964. Our native swans. In Waterfowl Tomorrow. U.S. Dept. of Interior, Washington. $770 \mathrm{pp}$.

BARD, F. C. 1953. The Trumpeter Swan. Blue Jay, I 1:26-27.

'DELACOUR, J. 1954. The waterfowl of the world. Vol. 1. Country Life Ltd., London. 284 pp.

EVENDEN, F. G. 1969. Report of Committee on Conservation, 1969. Auk, 86:738-744.
"LAHRMAN, F. W. 1961. A second pair of Trumpeter Swans nesting in Saskatchewan. Blue Jay, 19:18-19.

'LISTER, R. 1951. Trumpeter S'wans breeding in the Cypress Hills of Alberta. Can. Field-Nat., 65:157-158.

${ }^{*}$ MORRIS, W. A. 1971. Birds of British Columbia. In Canadian Wildlife Service '71. Canadian Wildlife Service, Ottawa. 88 pp.

"MUNRO, D. A. 1962. Trumpeter Swans. Canadian Audubon, 24:65-69.

"NIEMAN, D. J. 1971. A proposed plan for management of the Cypress Hills Trumpeter Swans. Unpublished report, Canadian Wild life Service. 8 pp.

"NIEMAN, D. J. 1972. Cypress Hills, Saskatchewan. Trumpeter Swans. Proceedings Second Trumpeter Swan Society Conference, Grande Prairie, Alberta. pp. 27-28.

12NIEMAN, D. J. 1972. Trumpeter Swans in the Cypress Hills. Blue Jay, Vol. XXX No. 2.

${ }^{1:}$ SYMONS, R. D. 1967. Hours and the birds. Univ. of Toronto Press, Toronto, $224 \mathrm{pp}$.

${ }^{4}$ TA VER NER, P. A. 1949. Birds of Canada. The Musson Book Co. Ltd., Toronto. 447 pp.

\title{
MORE HUDSONIAN GODWITS IN SASKATCHEWAN
}

\author{
by WAYNE C. HARRIS*
}

The Hudsonian Godwit has been onsidered an uncommon migrant in askatchewan. Until 1969 it was listed $n$ the Red Data Book as being a rare pecies. ${ }^{3}$ Even before they were emoved from the rare and enangered species list, Hudsonian Godits migrated through Saskatchewan, ut always in small numbers and inrequently. Most previous dates are of

Box 93

aymore, Sask

$0 \mathrm{~A} 3 \mathrm{~J} 0$ spring migrants. Fall migrants were considered rare. In fact, until 1970 numbers of Hudsonian Godwits over a flock of 15 had not been reported during fall migration. In 1970 and 1971 Gollop reported concentrations of Hudsonian Godwits for July and August and summarized all previous fall records from the Prairie Provinces to central Texas.' The following note reports more recent fall observations of Hudsonian Godwits in Saskatchewan. 